\title{
Using Mann Kendal and t-test methods in identifying trends of climatic elements: A case study of northern parts of Iran
}

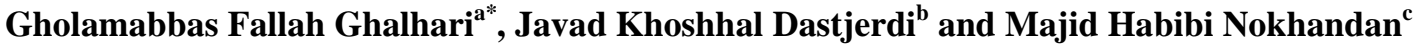

${ }^{a} \mathrm{PhD}$ student of climatology, Department of physical Geography, University of Isfahan, Iran

${ }^{b}$ Associated professor, Department of physical Geography, University of Isfahan, Iran

${ }^{c}$ Associated professor, Climatological Research Institute (CRI), Mashhad, Iran

\begin{tabular}{l}
\hline A R T I C L E I N F O \\
\hline Article history: \\
Received July 28, 2011 \\
Received in Revised form \\
October, 19, 2011 \\
Accepted 25 October 2011 \\
Available online \\
27 October 2011 \\
\hline Keywords: \\
Man Kendal test \\
T-test method \\
Climatic elements \\
Trend
\end{tabular}

\section{A B S T R A C T}

\begin{abstract}
The main objective of the present research is to examine trends change in climatic elements in the north of Iran. The daily data of minimum and maximum temperatures and precipitation of 6 stations of the area under study are retrieved from Iranian meteorological organization and the are used to calculate other parameters such as average and range of temperature in seasonal and annual scale. Then, Mann Kendal and T-test methods are used for cal-culating the change in aforementioned climatic parameters on seasonal and annual scale. The results of the research indicate a meaningful increasing trend in minimum, maximum and mean temperature and a meaningful decreasing trend in temperature range. Precipitation on seasonal and annual scale do not have significant trends.
\end{abstract}

\section{Introduction}

Significant increase in world population and various human activities has led to an increase in carbon dioxide concentration and other green-house gases (Bonsal et al., 2001). There are many documents about processes and long term changes, which are associated with effects of products made by human. Nowadays considering the important sources related to changes in atmosphere such as greenhouse gases, human activities are effective in climate change and make greenhouse gases such as CO2, CH4, NO2 and etc. (Jiang et al., 2005).

There are some evidences, which indicate that global warming has resulted from human activities in recent 50 years (Xu at al., 2003). Regional projections indicated that climate changes would intensify monsoon circulation, increase surface temperature, magnitude and frequency of extreme rainfall events (Fung et al., 2006).

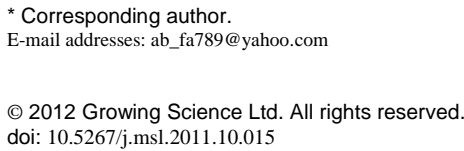


Climate change is considered as one of the main environmental problems of the 21st century (Pytrik et al., 2010). According to IPCC reports, the average land and ocean temperatures have increased between 0.3 to $0.6^{\circ} \mathrm{C}$ during 1900-1995 (IPCC 2001). Global warming and significant change in time series of temperature in different parts of the world could be considered as one of the most important signs of climate change in the 21st century (IPCC, 2007). Climate changes and global warming are effective on precipitation, hail, storm, flood and drought. They are very important in agricultural planning and policy, water management, environment, social and economical systems and human comfort (Domroes \& El-Tantawim, 2005).

Climate change has been investigated based on the analysis of different climatic variables. Temperature and rainfall time-series are much used in climatic variability analysis (Vicente, 2004). The analysis of long-term changes in climatic elements is a fundamental task in climate change studies (Huth \& Pokorna, 2004).

Due to the climate change importance, many countries analyze it in national and international levels. Identification and recognition of the climate change are the first steps of the analysis (Domroes \& ElTantawim, 2005). Considering the impact of climate changes on the environment, its recognition is very necessary (Azizi, 2004). For this reason, much research has been performed around the world. In the following, some examples are cited.

Ye et al. (1995) investigated climate change in the Arctic. Results indicated that a long-term warming was happening. Zheng and Basher (1999) used a statistical approach to identify time series models for annual mean temperature. Results showed that there was greater climate variation in the northern latitudes. Kaviani and Asakereh (2000) studied increasing precipitation trend of Isfahan's station for a period of 103 years. Results show lack of a meaningful trend in precipitation. Khalili and Bazrafshan (2003) investigated monthly, seasonal and annual precipitation trend across Iran. Results showed that there was no significant trend in Iran during the last 116 years. Climate patterns and trends in North Carolina were evaluated by Ryan and Sethu (2003). Results showed that precipitation has decreased during the summer. Results also revealed that precipitation has increased during the fall and winter. Vicente (2004) assessed the time-series of eight climatic variables in northeast of Brazil. Results indicated increasing trends in most of these variables. Mosmann et al. (2004) showed that summer precipitation had a meaningful trend in wide areas of Mainland Spain.

Sara et al. (2005) analyzed mean temperature and precipitation series over Castile and Leon in Spain in monthly, seasonal and annual time-scales. Results showed that there was a positive trend in the annual mean temperature for the whole period. Mohammed (2005) investigated global precipitation patterns. Results show that wet areas become wetter and dry areas become dryer.

Shirgholami and Ghahreman (2005) studied annual trend changes in 34 meteorological stations in Iran. Results showed that in 59\% of the stations, temperature changes had a positive trend and in $41 \%$ of the stations, temperature changes had a negative trend. Dry spells trend of Isfahan province in Iran, was evaluated by Nasri and Modarres (2008). Results indicated that the number of dry spells in two stations has been increased. Results also showed that the number of dry spells in one station has been decreased. Montazeri and Ghayour (2009) used standard precipitation index and Mann Kendal test for trend analysis of drought in the Caspian Sea basin. Results indicated that precipitation has no meaningful trend on January, May and December. Sohrabi et al. (2009) investigated annual precipitation trend of Hamedan Province in Iran using Mann-Kendall method. Results show the spatial irregular rainfall variability in the area under the study. The results of researches done in Northern east of Iran (Esmaili et al., 2009) showed that the length of the growth period has increased and the length of the freezing period has decreased due to temperature change.

Modarres (2009) analyzed rainfall trend in the last half of the twentieth century in Iran. Results revealed that the trends of annual rainfall began since 1970s for most of the stations. 
Extreme seasonal precipitation events were used as indicator for climate change by Indrani and Abir (2009). Results showed that there are large differences between trends in different seasons.

Yanxiang et al. (2010) simulated regional temperature and precipitation throughout the past 50 years and also the upcoming 30 years in China. Results showed that in upcoming 30 years, annual mean temperatures will increase across the Chinese Mainland. Liqiao et al. (2011) investigated precipitation variation in Northeastern China. Results indicated that the monthly precipitation rate has varied. Li et al. (2011) used daily climate indices in southwestern China during 1961-2008. Results revealed that the temperature of the warmest and coldest nights has increased. Yazdani et al. (2011) analyzed rainfall and temperature trend in Zayandehrud basin, Iran. Results indicated that there are no linear and nonlinear meaningful trends in rainfall time series on both annual and seasonal scale. The main objective of this study is identifying trends of climatic elements based on statistical methods in Mazandaran, Golestan and Gilan Province located in northern parts of Iran during 19762005.

\section{Data and methods}

\subsection{Data}

Daily meteorological data including minimum and maximum temperature mean temperature, the difference between minimum and maximum temperature (temperature range) as well as precipitation for the period 1976-2005, were considered from 6 synoptic stations across northern parts of Iran. The data is taken from Iranian meteorological organization. Note that the selected stations had recorded the data for 30 years. Fig. 1 shows studied area and the selected stations. Table 1 shows the descriptions of selected stations in the long term period. Annual and seasonal time series of the above mentioned climatic indicators are calculated for these stations.

\subsection{Method}

After collecting the data and filling the statistical data gaps, the climatic elements have been seasonally and annually calculated. The next step was the investigating of trend in climatic elements. To do so, Mann Kendal test and t-test method have been used. Helsel and Hirsch (1992) noted that the purpose of trend testing is to determine if the values of a random variable generally increase (or decrease) over some period of time in statistical terms (Onoz \& Bayazit, 2003). Parametric or nonparametric statistical tests can be used to decide whether there is a statistically significant trend. The null hypothesis $\mathrm{HO}$ indicates that there is no trend to be tested against the alternative and hypothesis $\mathrm{H} 1$, indicates that there is a trend. The parametric test such as t-test has less power than the nonparametric one such as Mann Kendal when the probability distribution is skewed (Onoz \& Bayazit, 2003). In the present paper, we have used Mann Kendal test as a non parametric method and t-test as a parametric method to trend detection of the data. Two methods are described briefly below.

\section{Table 1}

Weather stations and their related information in the long term period (1976-2005)

\begin{tabular}{|c|c|c|c|c|c|c|c|c|c|c|c|}
\hline \multirow[t]{2}{*}{ stations } & \multirow[t]{2}{*}{$\begin{array}{l}\text { Elevation } \\
\text { from sea } \\
\text { level (m) }\end{array}$} & \multicolumn{2}{|c|}{$\begin{array}{c}\text { Mean Annual } \\
\text { precipitation } \\
(\mathrm{mm})\end{array}$} & \multicolumn{2}{|c|}{$\begin{array}{c}\text { Minimum } \\
\text { Annual } \\
\text { temperature } \\
\left({ }^{\circ} \mathrm{C}\right) \\
\end{array}$} & \multicolumn{2}{|c|}{$\begin{array}{l}\text { Maximum } \\
\text { Annual } \\
\text { temperature } \\
\left({ }^{\circ} \mathrm{C}\right) \\
\end{array}$} & \multicolumn{2}{|c|}{$\begin{array}{l}\text { Temperature } \\
\text { range }\left({ }^{\circ} \mathrm{C}\right)\end{array}$} & \multicolumn{2}{|c|}{$\begin{array}{c}\text { Mean Annual } \\
\text { temperature } \\
\left({ }^{\circ} \mathrm{C}\right) \\
\end{array}$} \\
\hline & & $\mu$ & $\sigma$ & $\mu$ & $\sigma$ & $\mu$ & $\sigma$ & $\mu$ & $\sigma$ & $\mu$ & $\sigma$ \\
\hline Anzali & -20 & 1772 & 295 & 13.7 & 0.7 & 18.9 & 0.75 & 5.2 & 0.7 & 16.3 & 0.6 \\
\hline Rasht & -20.9 & 1363 & 250 & 11.9 & 0.45 & 20.4 & 0.73 & 8.5 & 0.48 & 16.1 & 0.55 \\
\hline Ramsar & -21 & 1216 & 303 & 12.8 & 0.8 & 19.3 & 0.66 & 6.5 & 0.6 & 16 & 0.66 \\
\hline Noshahr & 13.3 & 1250 & 291 & 12.3 & 2.37 & 18.9 & 3.62 & 6.6 & 1.3 & 15.6 & 3 \\
\hline Babolsar & 36.7 & 943 & 165 & 13.5 & 0.73 & 21 & 0.64 & 7.5 & 0.56 & 17.3 & 0.62 \\
\hline Gorgan & -26.2 & 568.2 & 91 & 12.8 & 0.72 & 22.8 & 0.72 & 10 & 0.56 & 17.8 & 0.66 \\
\hline
\end{tabular}




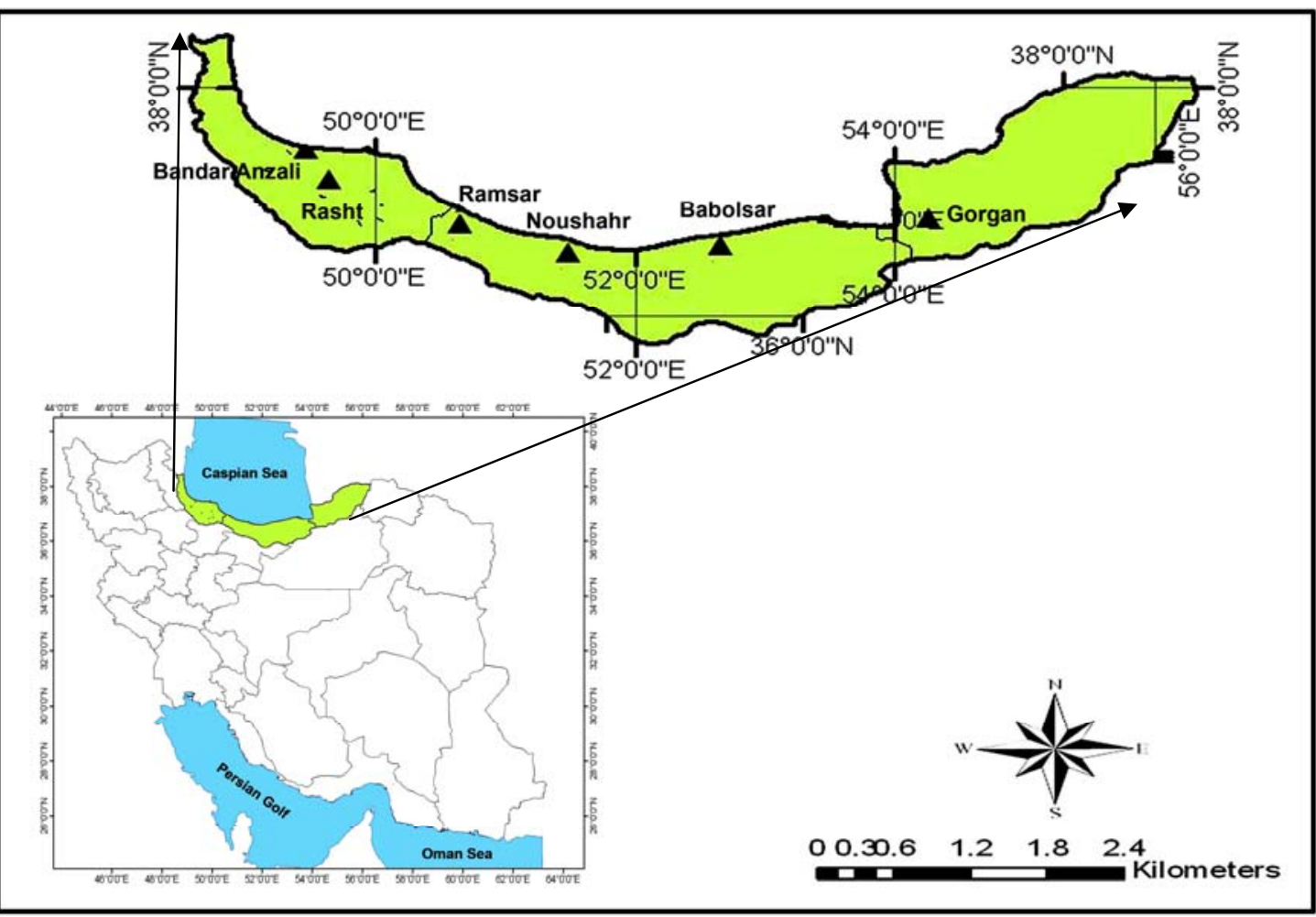

Fig. 1. Area under study and selected stations

\subsection{Mann Kendall Test}

The Mann-Kendall method has been suggested by the World Meteorological Organization to investigate the trend in environmental data time-series (Yu et al., 2002). Recent studies indicate that the most widely used method to detect the trend is the non-parametric Mann-Kendall trend test (Guhathakurta et al., 2010). This test consists of comparing each value of the time-series with the other remaining values, always in sequential order. The number of times indicates that the remaining terms are greater than those counted under analysis (Onoz \& Bayazit, 2003). The statistic $S$ is the sum of all the counts, given as follows:

$S=\sum_{i=2}^{n} \sum_{j=1}^{i-1} \operatorname{sign}\left(x_{i}-x_{j}\right)$

where $\operatorname{sign} x_{i}-x_{j}$ is

$$
\operatorname{sign}(x)=\left\{\begin{array}{lll}
1, & \text { for } & x_{i}-x_{j}>0 \\
0, & \text { for } & x_{i}-x_{j}=0 \\
-1, & \text { for } & x_{i}-x_{j}<0
\end{array}\right.
$$

The statistic $\mathrm{S}$ tends to normality for large n; with mean and variance defined as follows,

$E(S)=0$,

$V(S)=1 / 18\left[n(n-1)(2 n+5)-\sum_{P=1}^{q} t_{P}\left(t_{P}-1\right)\left(2 t_{P}+5\right)\right]$, 
where $n$ is the length of the times-series, $t_{p}$ is the number of ties for the $p^{\text {th }}$ value and $q$ is the number of tied values (i.e. equals values). The second term represents an adjustment for tied or censored data. The standardized test statistic $\mathrm{Z}$ is given by (Hirsch et al., 1982):

$Z= \begin{cases}\frac{S-1}{\sqrt{\operatorname{Var}(S)}} & \text { if } \quad S>0, \\ 0 & \text { if } \quad S=0, \\ \frac{S+1}{\sqrt{\operatorname{Var}(S)}} & \text { if } \quad S<0,\end{cases}$

The presence of a statistically significant trend is evaluated using the $Z$ value. This statistic is used to test the null hypothesis such that no trend exists. A positive $Z$ indicates an increasing trend in the time-series, while a negative $Z$ indicates a decreasing trend. To test either increasing or decreasing monotonic trend at $p$ significance level, the null hypothesis is rejected if the absolute value of $Z$ is greater than $Z_{1-P / 2}$; where $Z_{1-P / 2}$ is obtained from standard normal cumulative distribution tables. In the present paper, the significance levels of $P=0.01$ and $P=0.05$ was applied, and the significant level ( $p$-value) was obtained for each analyzed time series (Vicente, 2004).

\subsection{T-test}

The parametric $t$-test method considers the linear regression of the random variable $Y$ versus time $X$. The regression coefficient $b_{1}$ (or the Pearson correlation coefficient $r$ ) is computed from the data.

$t=\frac{r \sqrt{n-2}}{\sqrt{1-r^{2}}}=\frac{b_{1}}{s / \sqrt{S S_{x}}}$,

follows student's t distribution with degrees of freedom $n-2$, where $n$ is the sample size, $s$ is the standard deviation of residuals, and $S S_{x}$ is the sum of squares of the independent variables (time in trend analysis). The hypothesis $H_{0}: \rho=0$ (or $\beta_{1}=0$ ) is tested against the hypothesis $H_{1}: \rho \neq 0$ (or $\beta_{1} \neq 0$ ) at a chosen level of significance $\alpha$ where $\rho$ and $\beta_{1}$ are the population values of the correlation and regression coefficients, respectively. The hypothesis $H_{0}$ that indicates there is no trend rejected when the $t$ value computed by Eq. (6) is greater than the critical value $t_{\alpha / 2}$ in an absolute value (Haan, 1977; Onoz \& Bayazit, 2003).

\section{Results and discussion}

\subsection{Seasonal survey}

As mentioned earlier, seasonal and annual time series of climatic elements were analyzed. For example, Fig. 2 and Fig. 3 show seasonal and annual time series of mean temperature and precipitation versus time in the selected stations in the period 1976-2005.
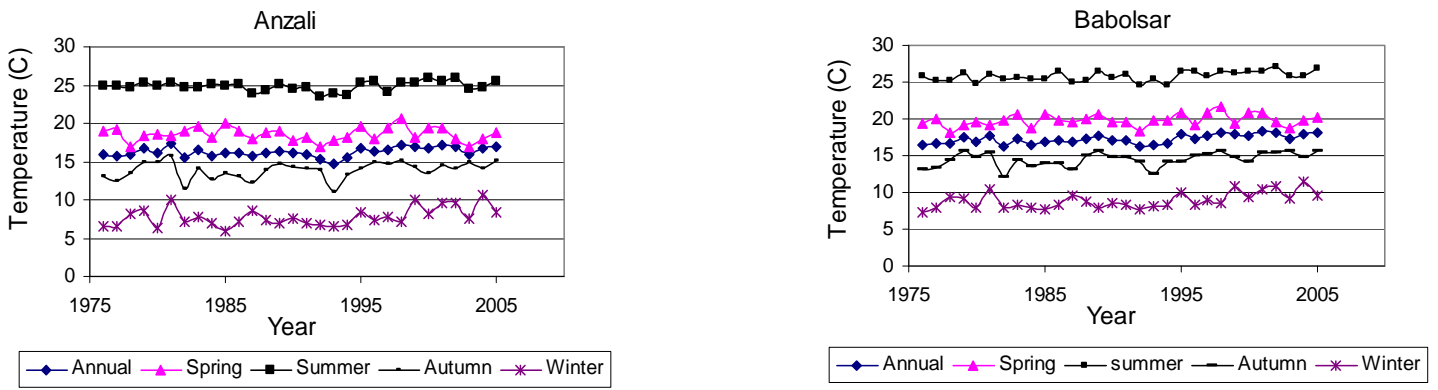

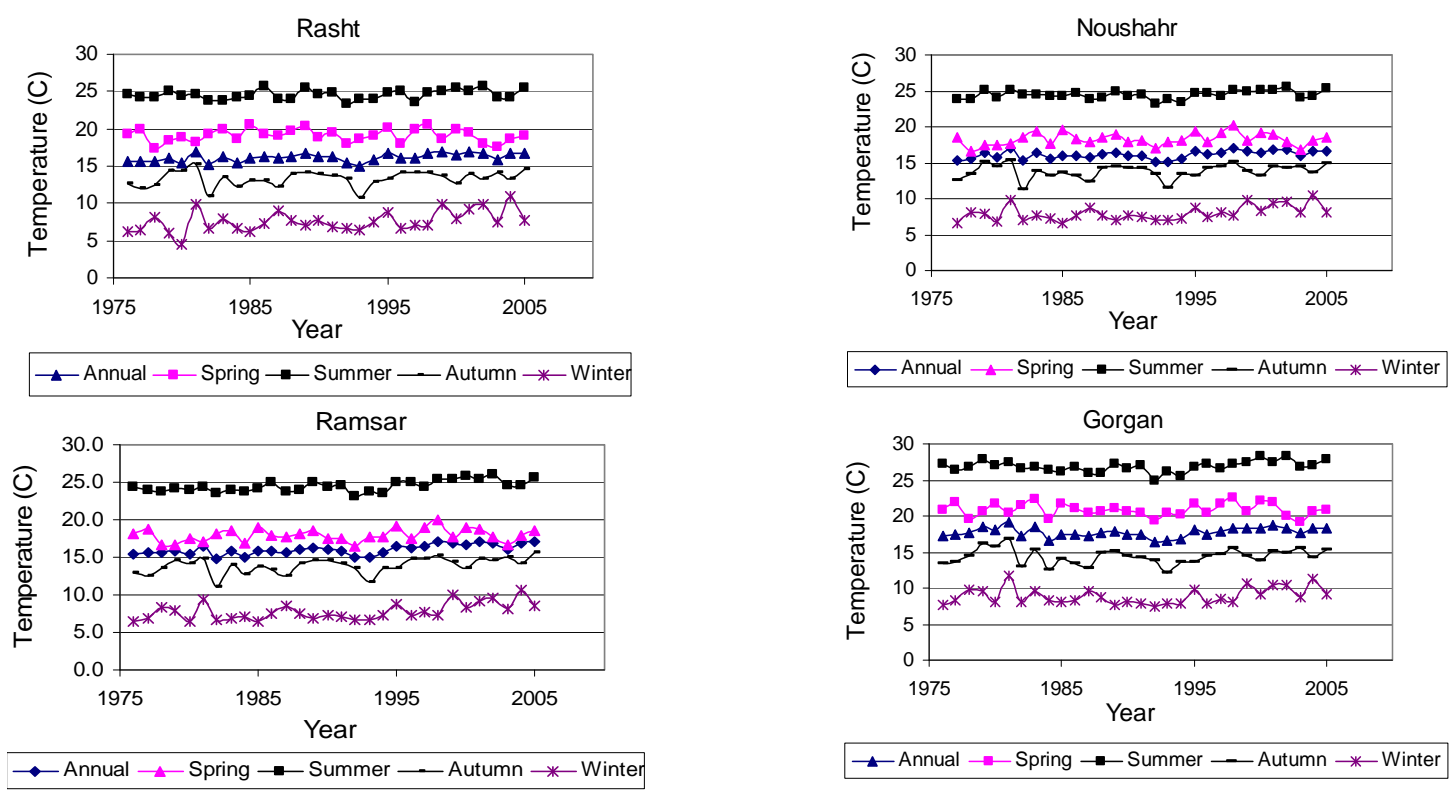

Fig. 2. Annual and seasonal time series of mean temperature versus time in the selected stations in the long term period (1976-2005)

Results of seasonal trend analysis are shown in Tables 2-6. Results of minimum temperature using both methods (Table 2) indicate that Anzali, Ramsar, Babolsar and Noshahr stations experienced a significant increasing trend. Using t-test method; Anzali, Ramsar and Babolsar stations show a significant positive trend in spring. The same situation is observed in Ramsar and Babolsar using Mann Kendal method. All stations indicate increasing trend in both methods in summer except Gorgan station. In autumn only Anzali, Ramsar and Babolsar experienced the significant increasing trend using both methods.

The analysis of maximum temperature trend (Table 3) in winter shows that using both methods, all stations show positive increasing trends, except Anzali station which has not experienced a significant trend. Only Anzali, Rasht and Ramsar stations have negative trend in spring using Man Kendal method but not significant. The same situation is observed in Anzali and Rasht stations using t-test method. In summer, just Anzali station has a negative significant trend. In autumn, no significant trend is observed.

Results of mean temperature seasonal trend (Table 4) using Mann Kendal method indicate that the mean temperature in Anzali station has an increasing trend in winter, summer and autumn. The same results are obtained using t-test method. In Rasht station, a decreasing trend is observed in spring. All stations (except Gorgan) have experienced a significant increasing trend using both methods in the winter. Trend was statistically significant using Mann Kendall and t-test method in all stations. Using Mann Kendal method in summer, the following stations experienced significant increasing trend: Ramsar, Noshahr, Babolsar and Gorgan. Anzali, Ramsar and Babolsar have increasing trend in autumn, while using t-test method, just Ramsar and Babolsar signify a meaningful trend.

The analysis of seasonal temperature range trend of the area under study (Table 5) signifies the negative trend in most stations. Using both methods, Babolsar and Gorgan stations have experienced a significant trend in winter; the former experiences a negative trend while the latter experiences a positive one. Anzali, Ramsar and Babolsar show significant decreasing trend using both methods in spring, summer and autumn.

The study of seasonal precipitation trend (Table 6) indicates that no station experienced either significant increasing or decreasing trend. As it is observed, the precipitation trends in winter go 
through a negative trend using both methods, except in Ramsar station. Using Mann Kendal method, trends of precipitation changes in Anzali, Rasht and Ramsar stations, are negative in autumn. The same outcomes are reported by t-test method except in Ramsar station which contains a positive trend. Also in summer, the following stations show negative trends using t-test method: Ramsar, Babolsar, Noshahr and Gorgan.
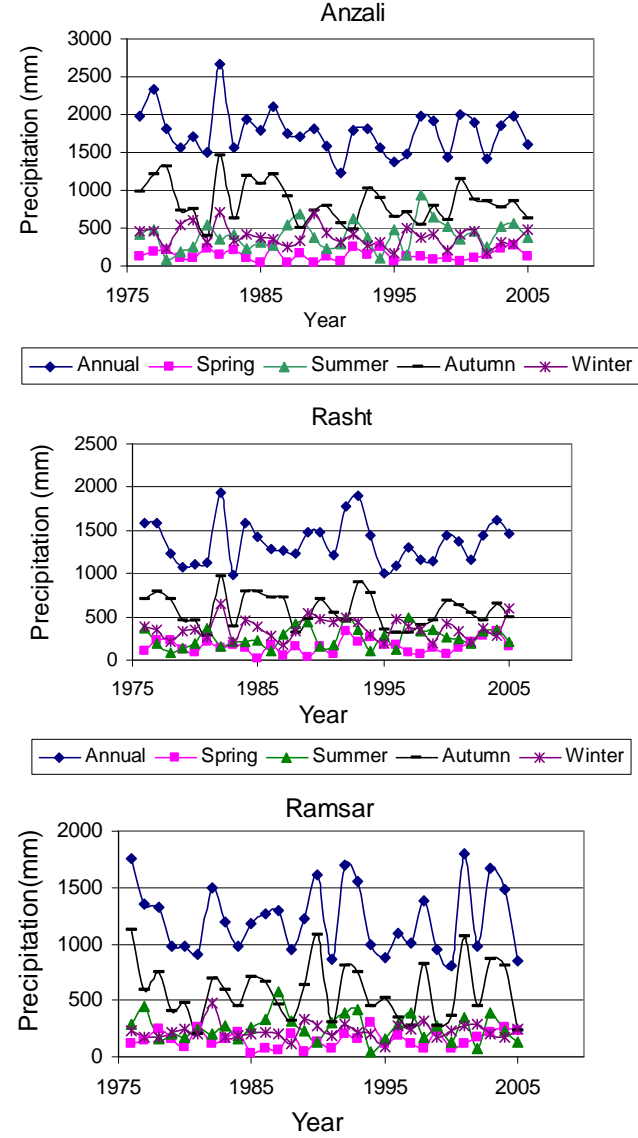

$\multimap$ Annual $\rightarrow$-Spring $\multimap$ Summer $\longrightarrow$ Autumn $\rightarrow$ Winter
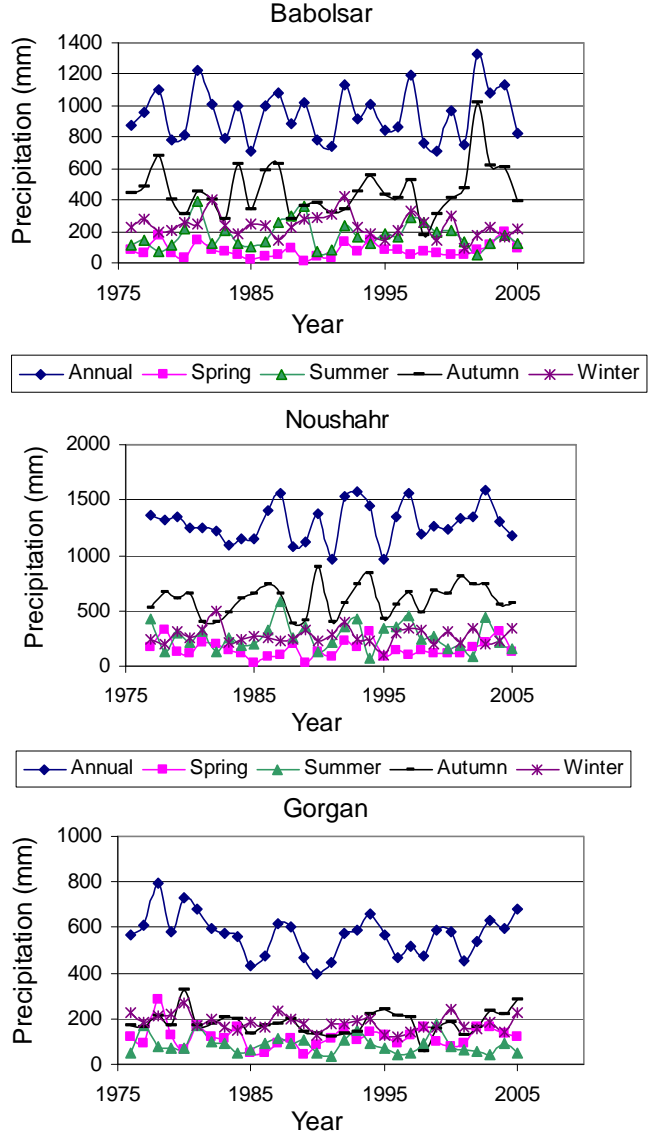

$\multimap$ Annual $\_$- Spring $\_$Summer — Autumn $*$ Winter

Fig. 3. Annual and seasonal time series of precipitation versus time in the selected stations in the long term period (1976-2005)

Table 2

The study of the seasonal minimum temperature trend in stations under study using Mann Kendal test and t-test method. Trend is significant If $|\mathrm{Z}|$ or $|\mathrm{t}|>1.96$. $\mathrm{Z}$ and $\mathrm{t}$ values for significant trends are in bold

\begin{tabular}{|c|c|c|c|c|c|c|c|c|c|c|c|c|c|c|c|c|}
\hline \multirow[b]{3}{*}{ Station } & \multicolumn{8}{|c|}{ t-test } & \multicolumn{8}{|c|}{ Mann Kendal test } \\
\hline & \multicolumn{2}{|c|}{ Autumn } & \multicolumn{2}{|c|}{ Summer } & \multicolumn{2}{|c|}{ Spring } & \multicolumn{2}{|c|}{ Winter } & \multicolumn{2}{|c|}{ Autumn } & \multicolumn{2}{|c|}{ Summer } & \multicolumn{2}{|c|}{ Spring } & \multicolumn{2}{|c|}{ Winter } \\
\hline & $\mathrm{t}$ & p-value & $\mathrm{t}$ & p-value & $\mathrm{t}$ & p-value & $\mathrm{t}$ & p-value & $\mathrm{z}$ & p-value & $\mathrm{z}$ & p-value & $\mathrm{z}$ & p-value & $\mathrm{z}$ & p-value \\
\hline Anzali & 2.8 & 0.009 & 5.5 & 00001 & 1.98 & 0.049 & 3.13 & 0.004 & 2.8 & 0.002 & 3.3 & 0.0004 & 1.78 & 0.09 & 2.8 & 0.002 \\
\hline Rasht & 1.53 & 0.13 & 3.32 & 0.002 & 0.06 & 0.95 & 1.12 & 0.27 & 1.1 & 0.13 & 2.9 & 0.001 & -0.17 & 0.42 & 1.07 & 0.14 \\
\hline Ramsar & 5.3 & 0.00001 & 5.41 & 00001 & 2.63 & 0.01 & 4.2 & 0.0004 & 4.1 & 0.00001 & 4.5 & 0.00002 & 2.2 & 0.01 & 3.3 & 0.0004 \\
\hline Noshahr & 1.2 & 0.24 & 2.44 & 0.02 & 0.99 & 0.33 & 3.9 & 0.004 & 1.4 & 0.07 & 2.4 & 0.007 & 1.18 & 0.11 & 2.3 & 0.009 \\
\hline Babolsar & 4.94 & 0.00001 & 4.85 & 00001 & 3.23 & 0.003 & 5.13 & 0.00001 & 4.06 & 0.00002 & 3.4 & 0.0002 & 3.1 & 0.0008 & 4.1 & 0.0002 \\
\hline Gorgan & 0.2 & 0.83 & 1.44 & 0.16 & -0.37 & 0.71 & 0.49 & 0.62 & 1.1 & 0.12 & 1.2 & 0.1 & -0.21 & 0.4 & 0.78 & 0.21 \\
\hline
\end{tabular}

Table 3

The study of the seasonal maximum temperature trend in stations under study using Mann Kendal test and t-test method

\begin{tabular}{|c|c|c|c|c|c|c|c|c|c|c|c|c|c|c|c|c|}
\hline \multirow[b]{3}{*}{ Station } & \multicolumn{8}{|c|}{ t-test } & \multicolumn{8}{|c|}{ Mann Kendal test } \\
\hline & \multicolumn{2}{|c|}{ Autumn } & \multicolumn{2}{|c|}{ Summer } & \multicolumn{2}{|c|}{ Spring } & \multicolumn{2}{|c|}{ Winter } & \multicolumn{2}{|c|}{ Autumn } & \multicolumn{2}{|c|}{ Summer } & \multicolumn{2}{|c|}{ Spring } & \multicolumn{2}{|c|}{ Winter } \\
\hline & $\mathrm{t}$ & p-val. & $\mathrm{t}$ & p-val. & $\mathrm{t}$ & p-val. & $\mathrm{t}$ & p-val. & $\mathrm{z}$ & p-val. & $\mathrm{z}$ & p-val. & $\mathrm{z}$ & $\frac{8}{\mathrm{p} \text {-val. }}$ & $\mathrm{z}$ & p-val. \\
\hline Anzali & 0.84 & 0.4 & -2.02 & 0.0535 & -1.86 & 0.07 & 1.75 & 0.08 & 1.32 & 0.09 & -1.53 & 0.06 & -1.74 & 0.06 & 1.67 & 0.071 \\
\hline Ramsar & 1.14 & 0.26 & 1.86 & 0.07 & 0.14 & 0.88 & 2.52 & 0.01 & 1.1 & 0.11 & 1.7 & 0.09 & -0.32 & 0.37 & 2.2 & 0.01 \\
\hline Noshahr & 1.22 & 0.23 & 1 & 0.32 & 0.75 & 0.45 & 2.51 & 0.01 & 1.06 & 0.14 & 1.27 & 0.1 & 0.84 & 0.19 & 2.3 & 0.009 \\
\hline Babolsar & 0.93 & 0.35 & 1.17 & 0.25 & 0.49 & 0.63 & 2.08 & 0.04 & -0.1 & 0.44 & -0.3 & 0.37 & 0.24 & 0.4 & 2.06 & 0.01 \\
\hline Gorgan & 1.25 & 0.22 & 1.64 & 0.11 & 1.37 & 0.18 & 2.2 & 0.03 & 1.6 & 0.0503 & 1.6 & 0.0903 & 1.2 & 0.1 & 2.1 & 0.01 \\
\hline
\end{tabular}


Table 4

The study of the seasonal maximum temperature trend in stations under study using Mann Kendal test and t-test method

\begin{tabular}{|c|c|c|c|c|c|c|c|c|c|c|c|c|c|c|c|c|}
\hline \multirow[b]{3}{*}{ Station } & \multicolumn{8}{|c|}{ t-test } & \multicolumn{8}{|c|}{ Mann Kendal test } \\
\hline & \multicolumn{2}{|c|}{ Autumn } & \multicolumn{2}{|c|}{ Summer } & \multicolumn{2}{|c|}{ Spring } & \multicolumn{2}{|c|}{ Winter } & \multicolumn{2}{|c|}{ Autumn } & \multicolumn{2}{|c|}{ Summer } & \multicolumn{2}{|c|}{ Spring } & \multicolumn{2}{|c|}{ Winter } \\
\hline & $\mathrm{t}$ & p-val. & $\mathrm{t}$ & p-val. & $\mathrm{t}$ & p-val. & $\mathrm{t}$ & p-val. & $\mathrm{z}$ & p-val. & $\mathrm{z}$ & p-val. & $\mathrm{z}$ & p-val. & $\mathrm{z}$ & p-val. \\
\hline Anzali & 1.76 & 0.09 & 1.03 & 0.31 & -0.27 & 0.88 & 2.57 & 0.1 & 2.1 & 0.01 & 0.82 & 0.2 & -0.4 & 0.33 & 2.4 & 0.006 \\
\hline Rasht & 1.37 & 0.18 & 1.68 & 0.1 & -0.37 & 0.7 & 2.25 & 0.03 & 1.39 & 0.08 & 1.6 & 0.5035 & 0.24 & 0.4 & 2.2 & 0.01 \\
\hline Ramsar & 2.84 & 0.008 & 4.59 & 0.00001 & 1.21 & 0.23 & 3.59 & 0.001 & 2.8 & 0.002 & 3.8 & 0.0006 & 0.92 & 0.17 & 3.1 & 0.0009 \\
\hline Noshahr & 1.28 & 0.21 & 1.75 & 0.09 & 1 & 0.32 & 2.73 & 0.01 & 1.25 & 0.1 & 2.04 & 0.04 & 0.88 & 0.18 & 2.6 & 0.004 \\
\hline Babolsar & 2.76 & 0.01 & 2.96 & 0.006 & 1.76 & 0.08 & 3.56 & 0.001 & 2.9 & 0.001 & 2.7 & 0.003 & 1.5 & 0.06 & 3.2 & 0.0005 \\
\hline Gorgan & 0.78 & 0.44 & 1.82 & 0.07 & 0.75 & 0.45 & 1.5 & 0.14 & 1.5 & 0.0903 & 2.4 & 0.02 & 0.53 & 0.29 & 1.6 & 0.0541 \\
\hline
\end{tabular}

Table 5

The study of the seasonal temperature range trend in stations under study using Mann Kendal test and t-test method

\begin{tabular}{|c|c|c|c|c|c|c|c|c|c|c|c|c|c|c|c|c|}
\hline \multirow[b]{3}{*}{ Station } & \multicolumn{8}{|c|}{ t-test } & \multicolumn{8}{|c|}{ Mann Kendal test } \\
\hline & \multicolumn{2}{|c|}{ Autumn } & \multicolumn{2}{|c|}{ Summer } & \multicolumn{2}{|c|}{ Spring } & \multicolumn{2}{|c|}{ Winter } & \multicolumn{2}{|c|}{ Autumn } & \multicolumn{2}{|c|}{ Summer } & \multicolumn{2}{|c|}{ Spring } & \multicolumn{2}{|c|}{ Winter } \\
\hline & $\mathrm{t}$ & p-val. & $\mathrm{t}$ & p-val. & $\mathrm{t}$ & p-val. & $\mathrm{t}$ & p-val. & $\mathrm{z}$ & p-val. & $\mathrm{z}$ & p-val. & $\mathrm{z}$ & p-val. & $\mathrm{z}$ & p-val. \\
\hline Anzali & -2.42 & 0.02 & -6.84 & 0.00001 & -5.97 & 0.00001 & -1.25 & 0.22 & -2.1 & 0.01 & -3.8 & 0.0005 & -3.8 & 0.0005 & -0.9 & 0.17 \\
\hline Rasht & 0.14 & 0.89 & -1.51 & 0.14 & -1.11 & 0.27 & 1.71 & 0.09 & 0.42 & 0.33 & -1.53 & 0.56 & -1.03 & 0.15 & 1.49 & 0.06 \\
\hline Ramsar & -3.55 & 0.0014 & -3.8 & 0.0007 & -2.1 & 0.04 & -1.51 & 0.14 & -3.1 & 0.0008 & -3.8 & 0.00006 & -2.9 & 0.001 & -1.1 & 0.11 \\
\hline Noshahr & 0.36 & 0.72 & -1.33 & 0.19 & 0.25 & 0.8 & 0.88 & 0.38 & 0.84 & 0.19 & -1.3 & 0.09 & 0.43 & 0.33 & 0.73 & 0.23 \\
\hline Babolsar & -5.46 & 0.0001 & -2.95 & 0.003 & -4.16 & 0.0003 & -2.43 & 0.02 & -4.4 & 0.008 & -2.9 & 0.001 & -3.5 & 0.0001 & -2.06 & 0.01 \\
\hline Gorgan & 1.24 & 0.22 & 0.26 & 0.79 & 1.89 & 0.06 & 3.13 & 0.004 & 0.99 & 0.15 & 0.64 & 0.26 & 1.6 & 0.0503 & 2.8 & 0.002 \\
\hline
\end{tabular}

Table 6

The study of the seasonal temperature range trend in stations under study using Mann Kendal test and t-test method

\begin{tabular}{|c|c|c|c|c|c|c|c|c|c|c|c|c|c|c|c|c|}
\hline \multirow[b]{3}{*}{ Station } & \multicolumn{8}{|c|}{ t-test } & \multicolumn{8}{|c|}{ Mann Kendal test } \\
\hline & \multicolumn{2}{|c|}{ Autumn } & \multicolumn{2}{|c|}{ Summer } & \multicolumn{2}{|c|}{ Spring } & \multicolumn{2}{|c|}{ Winter } & \multicolumn{2}{|c|}{ Autumn } & \multicolumn{2}{|c|}{ Summer } & \multicolumn{2}{|c|}{ Spring } & \multicolumn{2}{|c|}{ Winter } \\
\hline & $\mathrm{t}$ & p-val. & $\mathrm{t}$ & p-val. & $\mathrm{t}$ & p-val. & $\mathrm{t}$ & p-val. & $\mathrm{z}$ & p-val. & $\mathrm{z}$ & p-val. & $\mathrm{z}$ & p-val. & $\mathrm{z}$ & p-val. \\
\hline Anzali & -1.69 & 0.1 & 1.48 & 0.15 & -0.05 & 0.96 & -1.61 & 0.11 & -1.46 & 0.07 & 1.42 & 0.07 & -0.1 & 0.45 & -1.49 & 0.06 \\
\hline Rasht & -1.3 & 0.2 & 0.07 & 0.94 & 1.34 & 0.19 & -0.01 & 0.99 & -1.3 & 0.08 & 0.24 & 0.4 & 0.96 & 0.16 & -0.14 & 0.44 \\
\hline Ramsar & 0.04 & 0.97 & -0.29 & 0.79 & 1.5 & 0.14 & 0.48 & 0.63 & -0.49 & 0.3 & -0.1 & 0.45 & 0.93 & 0.16 & 1.17 & 0.11 \\
\hline Noshahr & 1.32 & 0.19 & -0.26 & 0.79 & 0.19 & 0.85 & -0.3 & 0.76 & 1.25 & 0.1 & 0.01 & 0.49 & 0.16 & 0.42 & -0.18 & 0.4 \\
\hline Babolsar & 0.8 & 0.43 & -0.07 & 0.94 & 1.25 & 0.22 & -1.25 & 0.22 & 0.42 & 0.3 & 0.24 & 0.4 & 0.89 & 0.18 & -1.2 & 0.11 \\
\hline Gorgan & 0.03 & 0.97 & -1.07 & 0.29 & -0.6 & 0.52 & -1.82 & 0.07 & 0.35 & 0.36 & -1 & 0.15 & -0.1 & 0.45 & -1.98 & 0.047 \\
\hline
\end{tabular}

\subsection{Annual survey}

Tables 7 and 8 illustrate the annual trend of climatic elements using Mann Kendal and t-test methods.

Table 7

The study of the annual climatic elements trend in stations under study using Mann Kendal test

\begin{tabular}{|c|c|c|c|c|c|c|c|c|c|c|}
\hline \multirow[b]{2}{*}{ station } & \multicolumn{2}{|c|}{ Precipitation (mm) } & \multicolumn{2}{|c|}{ Temperature range $\left({ }^{\circ} \mathrm{C}\right)$} & \multicolumn{2}{|c|}{ Mean temperature $\left({ }^{\circ} \mathrm{C}\right)$} & \multicolumn{2}{|c|}{$\begin{array}{l}\text { Maximum temperature } \\
\left({ }^{\circ} \mathrm{C}\right)\end{array}$} & \multicolumn{2}{|c|}{$\begin{array}{l}\text { Minimum temperature } \\
\left({ }^{\circ} \mathrm{C}\right)\end{array}$} \\
\hline & $\mathrm{Z}$ & p-value & $\mathrm{z}$ & p-value & $\mathrm{z}$ & p-value & $\mathrm{Z}$ & p-value & $\mathrm{z}$ & p-value \\
\hline Anzali & -0.89 & 0.81 & -3.67 & 0.0001 & 2.1 & 0.01 & 0.17 & 0.42 & 3.3 & 0.0003 \\
\hline Rasht & -0.35 & 0.63 & 0.39 & 0.34 & 2.39 & 0.008 & 2.3 & 0.02 & 2.74 & 0.003 \\
\hline Ramsar & 0.24 & 0.4 & -3.5 & 0.0002 & 4.1 & 0.00002 & 2.5 & 0.005 & 5.1 & 0.00001 \\
\hline Noshahr & 0.43 & 0.33 & 0.58 & 0.28 & 2.7 & 0.003 & 2.2 & 0.01 & 2.8 & 0.002 \\
\hline Babolsar & 0.42 & 0.33 & -4.8 & 0.00001 & 0.94 & 0.17 & 2.3 & 0.02 & 2.1 & 0.01 \\
\hline Gorgan & -1.1 & 0.13 & 2.9 & 0.001 & 2.06 & 0.01 & 2.42 & 0.007 & 1.32 & 0.09 \\
\hline
\end{tabular}

Table 8

The study of the annual climatic elements trend in stations under study using t-test method

\begin{tabular}{|c|c|c|c|c|c|c|c|c|c|c|}
\hline \multirow[b]{2}{*}{ station } & \multicolumn{2}{|c|}{ Precipitation (mm) } & \multicolumn{2}{|c|}{ Temperature range $\left({ }^{\circ} \mathrm{C}\right)$} & \multicolumn{2}{|c|}{ Mean temperature $\left({ }^{\circ} \mathrm{C}\right)$} & \multicolumn{2}{|c|}{ Maximum temperature $\left({ }^{\circ} \mathrm{C}\right)$} & \multicolumn{2}{|c|}{ Minimum temperature $\left({ }^{\circ} \mathrm{C}\right)$} \\
\hline & $\mathrm{t}$ & p-value & $\mathrm{t}$ & p-value & $\mathrm{t}$ & p-value & $\mathrm{t}$ & p-value & $t$ & p-value \\
\hline Anzali & -1.29 & 0.2 & -5.86 & 0.00001 & 2.15 & 0.04 & -0.16 & .87 & 5.2 & 0.00001 \\
\hline Rasht & -0.41 & 0.68 & 0.23 & 0.82 & 2.32 & 0.02 & 1.91 & 0.06 & 2.69 & 0.01 \\
\hline Ramsar & 0.21 & 0.83 & -4.42 & 0.0001 & 4.91 & 0.0001 & 2.77 & 0.009 & 6.25 & 0.000001 \\
\hline Noshahr & 0.81 & 0.42 & 0.33 & 0.74 & 2.77 & 0.01 & 2.22 & 0.03 & 2.97 & 0.006 \\
\hline Babolsar & 0.6 & 0.55 & -6.84 & 0.000001 & 4.5 & 0.0001 & 1.94 & 0.0504 & 2.14 & 0.04 \\
\hline Gorgan & -1.38 & 0.17 & 2.72 & 0.011 & 1.78 & 0.08 & 2.67 & 0.01 & 0.62 & 0.53 \\
\hline
\end{tabular}

As we see using both methods, the minimum temperature experienced a significant increasing trend in most stations (except Gorgan) where the trend is statistically significant at $1 \%$ level. The maximum temperature trend using both methods is different such that, using Mann Kendal method; all stations show increasing trend except Anzali station. However, when t-test method is used, only Noshahr, Ramsar and Gorgan experience a significant trend. The mean temperature in all stations has increasing trend. But when Mann Kendal method is used, only Babolsar station does not show any significant trend. In t-test method, Gorgan station does not show any significant trend. Only in Anzali, Ramsar and Babolsar stations, the temperature range using both methods indicates a 
significant decreasing trend and in others, the trend is increasing but not significant. Precipitation trend in annual survey in Anzali, Rasht, and Gorgan stations is negative and in Noshahr, Babolsar, and Ramsar stations, it is increasing; but none are significant at 5\% level.

\section{Conclusion}

In seasonal scale (tables 2-6); the mean, minimum and maximum temperature experienced an increasing trend in most seasons; however, the temperature range is in the opposite manner. Precipitation is a negative trend in winter; of course, this trend is just significant in Gorgan station. The annual study (tables 7-8) shows a positive trend in all vriables other than the temperature range which shows a meaningful negative trend (no meaningful trend was identified in precipitation). Considering the results of the present research, it will be possible to identify the consequences of climate change in Northern Iran, and taking appropriate measures; the extent of possible damages caused by change in climatic elements, can be minimized.

\section{References}

Asgari A., Rahimzadeh F. (2008). Trend analysis of extreme precipitation indices over Iran. Iranian Water Resources Research, 3(3), 42-55.

Azizi, G.H. (2004). Climate change. $1^{\text {st }}$ ed., Ghumes Publication, 274 pp. ISBN: 964-5516-87-0.

Bonsal, B.R.X., Zhang, L., Vicent, A., \& Ogg, W.D.H. (2001). Characteristics of daily and extreme temperature Canada. Journal of Climate, 14, 1959-1979.

Domroes, M., \& El-Tantawim A. (2005). Recent temporal and spatial temperature changes in Egypt. International Journal of Climate, 25, 51-63.

Esmaili, R., Habibi Nokhandan, M., Fallah Ghalhari, Gh. A. (2009). The Changes Assessment of Growth Season Length and Freezing due to climate Fluctuation- Case-study: Khorasan Razavi Province. Geographical Research Quarterly, 42(73), 69.

Fung, C.F., Farquharson, F., \& Chowdhury, J. (2006). Exploring the impacts of climate change on water resources-regional impacts at a regional scale: Bangladesh. Climate Variability and ChangeHydrological Impacts (Proceedings of the 5th FRIEND World Conference held at Ha-vana, Cuba, November 2006), IAHS Publication, 308, 389-393.

Guhathakurta, P., Preetha M., Mazumdar A. B., \& Sreejith, O. P. (2010). Changes in extreme rainfall events and flood risk in India during the last century, National Climate Centre, Research Report No. 3.

Haan, C.T. (1977). Statistical Methods in Hydrology. The Iowa State University Press, Ames.

Helsel, D.R., \& Hirsch, R.M. (1993). Statistical Methods in Water Resources. Journal of Hydrology, 147(1-4), 197-198.

Hirsch, R.M., Slack, J.R., \& Smith, R.A. (1982). Techniques of trend analysis for monthly water quality data. Water Resources, 18, 107-121.

Huth, R., \& Pokorna, L. (2004). Parametric versus non-parametric estimates of climatic trends, Theoretical and Applied Climatology, 77, 107-112.

Indrani, P., \& Abir, A.T. (2009). Trends in seasonal precipitation extremes - An indicator of 'climate change' in Kerala, India. Journal of Hydrology, 367(1-2), 62-69.

IPCC (2001). Cambridge University press, $1^{\text {st }}$ ed.

IPCC (2007). Summary for Policymakers. In: Climate Change 2007: The Physical Science Basis. Contribution of Working Group I to the Fourth Assessment Report of the Intergovernmental Panel on Climate Change. Cambridge University Press, Cambridge, United Kingdom.

Jiang, T., Su, B., \& Hartmann, H. (2006). Temporal and spatial trends of precipitation and river flow in the Yangtze river basin, 1961-2000. Geomorphology, 85, 143-154.

Kalili A., Bazrafshan J. (2003). A trend analysis of annual, seasonal and monthly precipitation over Iran during the last 116 years. Desert, 9(1), 25-33. 
Kaviani, M., \& Asakereh. H. (2003). Long-term investigation of annual precipitation of Isfahan, 3rd Regional Conference on Climate Change, 21-23 Oct, University of Isfahan, Iran.

Li, Z., Yuanqing, H., Puyu, W., Wilfred, H.T., Wenling, A., Xufeng, W., Lu, A., Wei, Z., Weihong, C. (2011). Changes of daily climate extremes in southwestern China during 1961-2008, Global and Planetary Change, In Press, Corrected Proof, Doi:10.1016/j.gloplacha.2011.06.008.

Liqiao, L., Lijuan, L., Qiang, L. (2011). Precipitation variability in Northeast China from 1961 to 2008. Journal of Hydrology, 404 (1-2), 67-76.

Modarres, R. (2009). Rainfall trends analysis of Iran in the last half of the twentieth century. Journal of Geophysical Research-Atmospheres, 114.

Dore, M.H.I. (2005). Climate change and changes in global precipitation patterns: What do we know? Environment International, 31(8), 1167-1181.

Mosmann, V., Castro, A., Fraile, R., Dessens, J., Sánchez, J.L. (2004). Detection of statistically significant trends in the summer precipitation of mainland Spain. Atmospheric Research, 70(1), 43-53.

Nasri \& Modarres (2008). Analysis dry spells trend of Isfahan Province in Iran. Journal of the Iranian Natural Resources, 61 (3), 589-60.

Onoz, B., \& Bayazit, M. (2003). The power of statistical tests for trend detection. Turkish Journal of Engineering Environmental Science, 27, 247-251.

Pytrik, R., Frank, E., Alfons, O. L., \& Rik, L. (2010). Adaptation to climate change and climate variability in European agriculture: The importance of farm level responses. European Journal of Agronomy, 32(1), 91-102.

Boyles, R.P., \& Raman, S. (2003). Analysis of climate trends in North Carolina (1949-1998), Environment International, 29 (2-3), 263-275.

Sara del, R., \& Ángel, P., Roberto, F. (2005). Analysis of recent climatic variations in Castile and Leon (Spain). Atmospheric Research, 73, (1-2), 69-85.

Shirgholami H., \& Ghahraman B. (2005). Study of time trend changes in annual mean temperature of Iran JWSS. Isfahan University of Technology, 2005, 9 (1), 9-24.

Sohrabi, M.M., Marofi, S., Sabziparva, A.A., Maryanaji, Z. (2009). Investigation of existence of trend in annual precipitation of Hamedan Province using Mann-Kendall method. Journal of Water and Soil Conservation, 16(3), 163-169.

da Silva, V. de P. R. (2004). On climate variability in northeast of Brazil. Journal of Arid Environment. 58, 575-596.

Xu, Z.X., Takeuchi K., \& Ishidaira H. (2003). Monotonic trend and step changes in Japanese precipitation. Journal of Hydrology, 279, 144-150.

Xuebin, Z., Lucie, A., Vincent, W., Hogg, D., \& Ain, N. (2000). Temperature and Precipitation Trends in Canada during the 20th Century. Atmospher-Ocean, 38(3), 395-429.

Yanxiang, L., Xiang, L., Qiang, Z., Yufu, G., Ge, G., Jianping, W. (2010). Simulation of regional tempera-ture and precipitation in the past 50 years and the next 30 years over China, Quaternary International, 212( 1), 57-63.

Yazdani, M.R., Khoshhal, J., Mahdavi, M., Sharma, A. (2011). Trend detection of rainfall and air temperature data in the Zayandehrud basin. Journal of Applied Science, 11(12), 2125-2134.

Ye, H., Kalkstein, L.S., \& Greene, J.S. (1995). The detection of climate change in the Arctic: an updated report. Atmospheric Research, 37 (1-3), 163-173.

Zheng, X., \& Basher, R.E. (1999). Structural time series models and trend detection in global and regional temperature series. Journal of Climate, 12, 2347-2358 . 